Joanna Leszczyńska

Uniwersytet $w$ Bialymstoku

\title{
POJĘCIE ,ZRÓWNOWAŻONEGO ROZWOJU” W USTAWIE O PLANOWANIU I ZAGOSPODAROWANIU PRZESTRZENNYM
}

Zgodnie z treścią przepisu art. 1 ust. 1 ustawy o planowaniu i zagospodarowaniu przestrzennym, ${ }^{1}$ ład przestrzenny i zrównoważony rozwój jest podstawą działań dotyczących zasad kształtowania polityki przestrzennej przez jednostki samorządu terytorialnego i organy administracji rządowej, a także czynności związanych z zakresem i sposobem postępowania $\mathrm{w}$ sprawach przeznaczania terenów na określone cele oraz ustalania zasad ich zagospodarowania i zabudowy. W związku z powyższym zdefiniowanie pojęcia zrównoważonego rozwoju jest istotne w świetle całokształtu działań podejmowanych na podstawie ustawy, związanych z planowaniem i zagospodarowaniem przestrzennym.

Pojęcie ,zrównoważonego rozwoju” funkcjonowało na gruncie poprzednio obowiązującej ustawy ${ }^{2}$ (w pierwotnym brzmieniu ustawy mowa była o „ekorozwoju”). Wówczas nakaz uwzględniania tej wartości określano jako konieczność „,zachowania równowagi pomiędzy wszystkimi elementami, składającymi się na środowisko, w którym bytuje człowiek, aby przy racjonalnym wykorzystaniu potencjału przyrodniczego możliwe było zaspokajanie potrzeb obecnych i przyszłych pokoleń". ${ }^{3}$ $\mathrm{W}$ obecnym stanie prawnym, wskazując w art. 1 u.p.z.p. zrównoważony rozwój jako podstawę podejmowanych działań, ustawodawca podkreślił istotne znaczenie tej wartości $\mathrm{w}$ praktyce funkcjonowania administracji. ${ }^{4} \mathrm{Na}$ gruncie u.p.z.p. poję-

1 Ustawa z dnia 27 marca 2003 r. - o planowaniu i zagospodarowaniu przestrzennym, Dz.U. z 2012 r., poz. 647 z późn. zm.; dalej jako: u.p.z.p.

2 Ustawa z dnia 7 lipca 1994 r. o zagospodarowaniu przestrzenny, tekst jedn.: Dz.U. z 1999 r. Nr 15, poz. 139 z późn. zm.; dalej jako: u.z.p.

3 M. Szewczyk, [w:] Z. Leoński, M. Szewczyk, Zasady prawa budowlanego i zagospodarowania przestrzennego, Bydgoszcz-Poznań 2002, s. 43. Por. także: W. Radecki, J. Sommer, W. Szostek, Ustawa o zagospodarowaniu przestrzennym oraz wybrane przepisy wykonawcze. Komentarz, Wrocław 1995, s. 12.

4 Do pojęcia „zrównoważonego rozwoju” odwołują się również składy orzekające sądów administracyjnych. Por. m.in. wyrok WSA w Lublinie z dnia 29 stycznia 2013 r., II SA/Lu 1009/12; wyrok NSA z dnia 21 września 2010 r., sygn. akt II OSK 1424/09. Jak wskazał Wojewódzki Sąd Administracyjny w Lublinie, z treści definicji wynika, że w ramach zasady zrównoważonego rozwoju mieści się nie tylko ochrona przyrody, ale i troska o rozwój społeczny i cywilizacyjny, związany z koniecznością budowania stosownej infrastruktury, por. Wyrok Wojewódzkiego Sądu 
cie to definiowane jest poprzez odesłanie do definicji legalnej zawartej w ustawie Prawo ochrony środowiska. ${ }^{5}$ Zgodnie z art. 3 pkt 50 u.p.z.p. pod pojęciem zrównoważonego rozwoju należy rozumieć taki rozwój społeczno-gospodarczy, w którym następuje proces integrowania działań politycznych, gospodarczych i społecznych, z zachowaniem równowagi przyrodniczej oraz trwałości podstawowych procesów przyrodniczych, w celu zagwarantowania możliwości zaspokajania podstawowych potrzeb poszczególnych społeczności lub obywateli zarówno współczesnego pokolenia, jak i przyszłych pokoleń. ${ }^{6}$ Odesłanie w u.p.z.p. do rozumienia terminu ,zrównoważonego rozwoju" określonego w p.o.ś. należy ocenić pozytywnie. Należy bowiem pamiętać, że działalność związana z planowaniem i zagospodarowaniem przestrzeni jest bez wątpienia nierozerwalnie związana $z$ innymi dziedzinami prawa, przede wszystkim prawem ochrony środowiska. Przejmowanie tym samym pojęcia przez u.p.z.p. zawartego w u.o.ś. ma zapewnić swego rodzaju zgodność rozwiązań zawartych w tych dwóch aktach prawnych.

Zgodnie z poglądami wyrażanymi przez przedstawicieli doktryny, wartość normatywna przepisów określających zakres regulacji zawartych w danym akcie prawnym, a do takich przepisów należy zaliczyć art. 1 ust. 1 u.p.z.p. jest ograniczona i co do zasady nie wywołuje bezpośrednich skutków prawnych, jednakże ma znaczenie w kontekście interpretacji całokształtu przepisów, zawartych w danym akcie normatywnym. ${ }^{7}$ Wynika to także z zamieszczenia wspomnianego przepisu w rozdziale 1 u.p.z.p., zatytułowanym „Przepisy ogólne”, co też powoduje, że uregulowania tej części ustawy należy stosować do wszelkich działań podejmowanych w ramach działalności planistycznej, także jeśli chodzi o stanowienie przepisów wykonawczych do ustawy.

W art. 1 u.p.z.p. przewidziano ponadto, że podmioty w trakcie swojej działalności związanej z ustawą, powinny uwzględniać także inne wartości, określone w ust. 2, tj. m.in.: walory architektoniczne i krajobrazowe, wymagania ochrony środowiska, w tym gospodarowania wodami i ochrony gruntów rolnych i leśnych, wymagania ochrony dziedzictwa kulturowego i zabytków oraz dóbr kultury współczesnej, wymagania ochrony zdrowia oraz bezpieczeństwa ludzi i mienia, a także potrzeby osób niepełnosprawnych. Wartości te, obok ładu przestrzennego i zrównoważonego

Administracyjnego w Lublinie z dnia 11 września 2012 r., II SA/Lu 272/12; wyrok NSA z dnia 26 października 2011 r., II OSK 1820/11.

5 Ustawa z dnia 27 kwietnia 2001 r.- Prawo ochrony środowiska (tekst jedn.: Dz.U. z 2008 r. Nr 25, poz. 150 z późn. zm. dalej jako: p.o.ś.

6 Pojęcie zrównoważonego rozwoju występuje także na gruncie innych dziedzin prawa, w tym przede wszystkim w obszarze prawa konstytucyjnego (por. art. 5 Konstytucji RP) i europejskiego. Do tego terminu odnosi się m.in. wspólna polityka rybołówstwa. Zgodnie z art. 2 Rozporządzenia Rady (WE) nr 2371/2002 z dnia 20 grudnia 2002 r. w sprawie ochrony i zrównoważonej eksploatacji zasobów rybołówstwa w ramach wspólnej polityki rybołówstwa, wspólna polityka rybołówstwa zapewnia taką eksploatację żywych zasobów wodnych, która zapewnia zrównoważone warunki ekonomiczne, środowiskowe i społeczne. z komentarzem i przepisami wykonawczymi, Warszawa 1995, s. 9. 
rozwoju, powinny odgrywać istotną rolę w planowaniu i zagospodarowaniu przestrzenny. ${ }^{8}$ Wydaje się, że określone w tym ustępie wartości korelują z regulacją zawartą w art. 1 ust. 1 u.p.z.p. Należy bowiem zaznaczyć, że ustawodawca wpierw wskazuje, że w określonej ustawą działalności podstawą czynności podejmowanych w jej ramach ma być m.in. zrównoważony rozwój, a w ust. 2 tego artykułu wskazuje, że należy uwzględnić w szczególności wskazane wyżej wartości.

Taka redakcja przepisów zdaje się wskazywać, że wartości wymienione w art. 1 ust. 2 u.p.z.p. ${ }^{9}$ zawierają się w pojęciu ładu przestrzennego lub zrównoważonego rozwoju, choć mogą wystąpić także inne, nieujęte w tym przepisie. Innymi słowy ład przestrzenny i zrównoważony rozwój stanowią zasadę działania organów administracji publicznej w ramach aktywności podejmowanej w zakresie określonym w art. 1 ust. 1, natomiast uwzględnianie wartości określonych w ust. 2 prowadzi do działalności zgodnej z tymi podstawowymi zasadami. Wskazać przy tym należy, że katalog wartości określonych w art. 1 ust. 2 nie ma charakteru zamkniętego (na co wskazuje użycie sformułowania: „w szczególności”), stąd też mogą wystąpić inne wartości określone ustawowo. ${ }^{10}$ Możliwe jest również nieco odmienne ujęcie wskazanych wartości w ten sposób, że ład przestrzenny i zrównoważony rozwój są odrębnymi zasadami, które stanowią podstawę działań określonych w art. 1 ust. 1 u.p.z.p., natomiast w samym planowaniu i zagospodarowaniu przestrzennym należy uwzględniać wartości określone ustawowo w art. 1 ust. 2 u.p.z.p.

Warto zastanowić się zatem nad charakterem prawnych wskazanych w art. 1 u.p.z.p. zasad. ${ }^{11}$ Określenie ,zasady” zostało użyte celowo. Pod tym pojęciem rozumiem bowiem (na gruncie niniejszego opracowania) normy prawne o podstawowym znaczeniu dla planowania i zagospodarowania przestrzennego. ${ }^{12} \mathrm{~W}$ doktrynie wskazuje się, że określone w art. 1 wartości można interpretować jako przepisy odsyłające bądź jako pojęcia niedookreślone. Przy pierwszym ujęciu, rola tych przepisów sprowadzałaby się do wskazania tylko obszarów materialnego prawa administracyjnego, uregulowanych odrębnymi ustawami, które to akty zawierają normy wiążące organy realizujące działania w sferze planowania i zagospodarowania przestrzen-

W doktrynie, na tle wskazanego przepisu, formułowana jest zasada uwzględniania w zagospodarowaniu przestrzennym wartości określonych ustawowo. Por. M. Szewczyk, [w:] Z. Leoński, M. Szewczyk, Zasady prawa budowlanego..., op. cit., s. 43 i n.; M. Szewczyk, [w:] Z. Leoński, M. Szewczyk, M. Kruś, Prawo zagospodarowania przestrzeni, Warszawa 2012, s. 50 i n. Z. Niewiadomski wyróżnia zasadę zrównoważonego rozwoju i zasadę ochrony innych wartości wysoko cenionych, Planowanie przestrzenne. Zarys systemu, Warszawa 2003, s. 34-38.

9 W tym miejscu warto przytoczyć stanowisko Trybunału Konstytucyjnego wyrażone w wyroku z dnia 8 lipca 2008 r., K 46/07: „Zgodnie z art. 1 ust. 2 (...) w planowaniu uwzględnia się zwłaszcza ład przestrzenny, walory architektoniczne i krajobrazowe, wymogi ochrony środowiska, dziedzictwa kulturowego i zabytków oraz zdrowia i bezpieczeństwa, a także walory ekonomiczne przestrzeni, potrzeby obronności i bezpieczeństwa państwa oraz potrzeby interesu publicznego. Tak więc już na tym etapie pod uwagę brane są wartości wymienione w art. 31 ust. 3 Konstytucji (bezpieczeństwo państwa, porządek publiczny, ochrona środowiska, zdrowia, prawa innych osób)." Tak też: H. Nowicki, [w:] Aspekty prawne planowania i zagospodarowania przestrzennego, W. Szwajdler (red.), Warszawa 2013, s. 23.

11 Zasada zrównoważonego rozwoju ma swoje źródło w Konstytucji RP, stąd też można zaliczyć ją do jednej z zasad ustrojowych.

12 W kwestii rozumienia pojęcia zasad prawa, por. J. Zimmermann, Prawo administracyjne, Warszawa 2012, s. 95. 
nego. Traktując wskazane przepisy jako zawierające pojęcie niedookreślone, należałoby je uważać za będące podstawą do rekonstrukcji normy prawnej. Przepisy te $\mathrm{w}$ tym ujęciu obowiązywałyby organy bezpośrednio. ${ }^{13} \mathrm{Na}$ gruncie poprzednio obowiązującej u.z.p. w literaturze wskazywano, że obowiązek uwzględniania wartości określonych w art. 1 tego aktu oznacza, że ów obowiązek istnieje w zakresie przewidzianym przez przepisy szczególne, zawartych zarówno w u.z.p., jak i innych aktach prawnych. W przypadku, gdy brak było takich przepisów szczególnych, to przepis art. 1 ust. $2^{14}$,tworzy wprost podstawy do ograniczeń zasady swobodnego korzystania z rzeczy, określonej w art. 140 k.c." ${ }^{15} \mathrm{~W}$ takich okolicznościach wartości te traktowano jako pojęcia niedookreślone. Na gruncie u.z.p. wskazywano także, że regulacja zawarta $\mathrm{w}$ art. 1 ust. 2 ma charakter przepisów odsyłających, oznaczających skrótowo uregulowania prawne dotyczące określonej problematyki.

Wydaje się, że przepis art. 1 należy traktować jako zawierający pojęcia niedookreślone. Dzięki takiemu ujęciu, dopiero akt, który został wydany przy uwzględnieniu wymienionych wartości, można uznać za zgodny z prawem. Należy tu poczynić jednak istotne zastrzeżenie. Wartości te nie mogą stanowić samoistnej, materialnoprawnej podstawy do wydawania decyzji o ustaleniu lokalizacji inwestycji celu publicznego i decyzji o warunkach zabudowy, co oczywiście nie oznacza, że organ nie powinien brać ich pod uwagę $\mathrm{w}$ trakcie prowadzonego postępowania administracyjnego. Ma to swoje odzwierciedlenie w art. 56 u.p.z.p. Zgodnie z treścią tego przepisu, przepis art. 1 ust. 2 nie może stanowić wyłącznej podstawy odmowy ustalenia lokalizacji inwestycji celu publicznego (przepis ten stosuje się odpowiednio do decyzji o warunkach zabudowy; por. art. 64 u.p.z.p.). Jak już zostało to podniesione wydaje się, że wartości określone w art. 1 ust. 2 zawierają się odpowiednio w pojęciu ładu przestrzennego lub zrównoważonego rozwoju (z zastrzeżeniem, że są to oczywiście terminy o szerszym zakresie pojęciowym), stąd też w pewnym zakresie i one nie będą mogły być wyłączną podstawą do odmowy wydania wyżej wskazanych aktów. Przepis art. $56 \mathrm{w}$ obecnym brzmieniu obowiązuje od 17 lipca 2010 r. Do zmiany stanu prawnego w tym zakresie w orzecznictwie sądów administracyjnych pojawiały się rozbieżności, w jaki sposób interpretować wartość zasad określonych $\mathrm{w}$ art. $1 .{ }^{16}$ Obecnie nie powinno już budzić żadnych wątpliwości twierdzenie, że zasada uwzględniania przez organy administracji w planowaniu i za-

13 Por. Z. Niewiadomski, Ustawa o planowaniu...., op. cit., s. 7.

14 W ówczesnym brzmieniu pokrywał się częściowo z obecnym uregulowaniem. Zgodnie z treścią art. 1 ust. 2 u.z.g, w zagospodarowaniu przestrzennym uwzględniało się zwłaszcza: 1) wymagania ładu przestrzennego, urbanistyki i architektury, 2) walory architektoniczne i krajobrazowe, 3) wymagania ochrony środowiska przyrodniczego, zdrowia oraz bezpieczeństwa ludzi i mienia, a także wymagania osób niepełnosprawnych, 4) wymagania ochrony dziedzictwa kulturowego i dóbr kultury, 5) walory ekonomiczne przestrzeni i prawo własności, 6) potrzeby obronności i bezpieczeństwa państwa.

15 R. Hauser, E. Mzyk, Z. Niewiadomski, M. Rzążewska, Ustawa o zagospodarowaniu przestrzennym..., op. cit., s. 9.

16 Por. m.in. wyrok Wojewódzkiego Sądu Administracyjnego w Rzeszowie, z dnia 4 października 2007 r., II SA/Rz 482/07, LEX nr 413507; wyrok Wojewódzkiego Sądu Administracyjnego w Poznaniu z dnia 18 września 2007 r., II SA/Po 245/07, CBOSA. Wyroki odmiennej treści zapadły na gruncie podobnego stanu faktycznego. 
Pojęcie „zrównoważonego rozwoju” w ustawie o planowaniu i zagospodarowaniu...

gospodarowaniu przestrzennym wymagań ładu przestrzennego i zrównoważonego rozwoju ma charakter normy ogólnej (klauzuli generalnej), która bezpośrednio nie nakłada na inwestorów żadnych ograniczeń w zakresie dopuszczalnego sposobu zabudowy i zagospodarowania terenu. W związku z powyższym należy zgodzić się ze stanowiskiem wojewódzkiego sądu administracyjnego w Poznaniu, który ocenił, że tego typu norma nie może być samodzielną podstawą do wydania decyzji odmownej w sprawie ustalenia lokalizacji inwestycji celu publicznego, a odmowa ustalenia lokalizacji inwestycji musi opierać się na wyraźnej sprzeczności zamierzenia inwestycyjnego z przepisem nakładającym wprost konkretne ograniczenia. Natomiast źródłem ograniczeń, jak podnosił sąd, mogą być tylko przepisy ustawy o planowaniu i zagospodarowaniu przestrzennym lub przepisy odrębne zawarte np. w ustawie o ochronie przyrody, ustawie Prawo ochrony środowiska, ustawie o ochronie zabytków i opiece nad zabytkami, ustawie o ochronie gruntów rolnych i leśnych, ustawie o gospodarce nieruchomościami itp. ${ }^{17}$

Do pojęcia zrównoważonego rozwoju na gruncie u.p.z.p. ustawodawca odnosi się wprost nie tylko w powołanym art. 1 ust. 1 u.p.z.p., lecz także w odniesieniu do koncepcji przestrzennego zagospodarowania kraju (por. art. 47 u.p.z.p.; dalej jako: „kpzp.”). Oczywiście nie oznacza to, że zasada ta nie obowiązuje w odniesieniu do pozostałych aktów przewidzianych u.p.z.p., ${ }^{18}$ wręcz przeciwnie - na mocy art. 1 u.p.z.p. odnosi się do wszelkich działań określonych w tym artykule. Zdaje się, że prawodawca wskazując wprost, iż przy sporządzaniu kpzp. uwzględnia się zasadę zrównoważonego rozwoju, starał się podkreślić jej istotne znaczenie w prowadzonej polityce przestrzennej na poziomie państwowym. W istocie w Koncepcji Przestrzennego Zagospodarowania Kraju $2030^{19}$ wielokrotnie odwołano się do pojęcia ,zrównoważonego rozwoju”. Z omawianej zasady wyprowadzono dalsze, takie jak: zasada racjonalności ekonomicznej (w ramach polityki przestrzennej uwzględniana jest ocena korzyści społecznych, gospodarczych i przestrzennych w długim okresie), zasada preferencji regeneracji (odnowy) nad zajmowaniem nowych obszarów pod zabudowę (intensyfikacja procesów urbanizacyjnych na obszarach już zagospodarowanych, tak aby minimalizować ekspansję zabudowy na nowe tereny), zasada przezorności ekologicznej (rozwiązywanie pojawiających się problemów powinno następować we właściwym czasie, tj. odpowiednie działania powinny być podejmowane już wówczas, gdy pojawia się uzasadnione przypuszczenie, że problem wymaga rozwiązania, a nie dopiero wtedy, gdy istnieje pełne tego naukowe potwierdzenie) oraz zasada kompensacji ekologicznej (polega na takim zarządzaniu przestrzenią, planowaniu i realizacji działań polityki rozwojowej, w tym przestrzen-

17 II SA/Po 245/07.

18 Wydaje się, że zasada ta nie będzie się odnosić tylko do aktów, przewidzianych u.p.z.p., lecz również innych, powiązanych z nimi, jak np. programy, o których mowa w art. 48 ust. 1; por. art. 47 ust. 3 u.p.z.p.

19 Akt dostępny za pośrednictwem witryny internetowej http://www.mrr.gov.pl/rozwoj_regionalny/Polityka_przestrzenna/KPZK/Strony/Koncepcja_Przestrzennego_Zagospodarowania_Kraju.aspx, (dostęp: 4 kwietnia 2013 r.). 
nej, aby zachować równowagę przyrodniczą i wyrównywać szkody w środowisku wynikające $z$ rozwoju przestrzennego, wzrostu poziomu urbanizacji i inwestycji niezbędnych ze względów społeczno-gospodarczych, a pozbawionych alternatywy neutralnej przyrodniczo). ${ }^{20} \mathrm{~W}$ odniesieniu natomiast do pozostałych aktów uregulowanych u.p.z.p. można wskazać, że ustawodawca w regulacjach prawnych, dotyczących poszczególnych instytucji, odnosi się również do pojęcia zrównoważonego rozwoju poprzez nakaz uwzględniania określonych uwarunkowań. Tytułem przykładu można wskazać na studium uwarunkowań i kierunków zagospodarowania przestrzennego gminy. W odniesieniu do tego aktu, ustawodawca przewidział, że w tym akcie należy uwzględnić m.in. uwarunkowania wynikające ze stanu środowiska, w tym stanu rolniczej i leśnej przestrzeni produkcyjnej, wielkości i jakości zasobów wodnych oraz wymogów ochrony środowiska, przyrody i krajobrazu kulturowego. Także w odniesieniu m.in. do miejscowego planu zagospodarowania przestrzennego, prawodawca przewidział rozwiązania prawne, mające na celu zapewnienie postępowania zgodnie $\mathrm{z}$ zasadą zrównoważonego rozwoju. $\mathrm{W}$ art. 15 ust. 2 u.p.z.p. określono obowiązkowe elementy miejscowego planu zagospodarowania przestrzennego, $\mathrm{tj}$. m.in. zasady ochrony środowiska, przyrody i krajobrazu kulturowego, czy też wymagania wynikające z potrzeb kształtowania przestrzeni publicznych, czy też plan zagospodarowania przestrzennego województwa, w którym określa się m.in. podstawowe elementy sieci osadniczej województwa i ich powiązań komunikacyjnych oraz infrastrukturalnych, w tym kierunki powiązań transgranicznych (por. art. 39 ust. 3 pkt 1 u.p.z.p.).

W tym miejscu warto podnieść, że działalność związana z planowaniem i zagospodarowaniem przestrzennym związana jest z koniecznością wyważania interesu publicznego i prywatnego. ${ }^{21} \mathrm{~W}$ praktyce powstaje wiele konfliktów, które rodzą się na tym tle. ${ }^{22}$

Mimo przyjęcia określonego rozumienia przepisu, nadal w praktyce mogą powstać wątpliwości interpretacyjne, związane z użyciem nieprecyzyjnych sformułowań (np. proces integrowania działań politycznych, gospodarczych i społecznych). Zdaje się zatem zasadne twierdzenie, że zrównoważony rozwój jest pojęciem wieloaspektowym i każdorazowo jego zakres będzie wyglądał nieco odmiennie. Za

21 Jak wskazuje się w orzecznictwie sądowym w państwie prawa nie ma miejsca dla mechanicznej i sztywno pojmowanej zasady nadrzędności interesu ogólnego nad interesem indywidualnym. Oznacza to, że w każdym przypadku działający organ ma obowiązek wskazać, o jaki interes ogólny (publiczny) chodzi i udowodnić, że jest on na tyle ważny i znaczący, że bezwzględnie wymaga ograniczenia uprawnień indywidualnych obywateli. Zarówno istnienie takiego interesu, jak i jego znaczenie, a także przesłanki powodujące konieczność przedłożenia w konkretnym wypadku interesu publicznego nad indywidualny podlegać muszą zawsze wnikliwej kontroli instancyjnej i sądowej, a już szczególnie wówczas, gdy chodzi o udowodnienie, iż w interesie publicznym leży ograniczenie (lub odjęcie) określonego przez Konstytucję RP prawa własności. Por. uzasadnienie wyroku WSA w Gdańsku z dnia 18 listopada 2008 r., sygn. akt II SA/Gd 281/08, LEX nr 509695.

22 Tytułem przykładu można wskazać na spór o treść miejscowego planu zagospodarowania przestrzennego nieruchomości położonych na terenie Dojlid Górnych, por. m.in. E. Sokólska, A. Kłopotowski, Dojlidy Górne niezgody. Mieszkańcy kontra magistrat, http://bialystok.gazeta.pl/bialystok/1,35250,11955262,Dojlidy_Gorne_niezgody_ Mieszkancy_kontra_magistrat.html, (dostęp: 3 kwietnia 2013 r.). 
Pojęcie „zrównoważonego rozwoju” w ustawie o planowaniu i zagospodarowaniu...

słusznością postawionej tezy przemawia także charakter wyliczonych w art. 1 ust. 2 zagadnień. Wydaje się bowiem, że organy podejmujące czynności związane z kształtowaniem i zagospodarowaniem przestrzeni, powinny uwzględniać w trakcie swoich działań wymienione w powyższym przepisie wymagania. Prowadzi to do konstatacji, że dopiero całościowe uwzględnienie wszystkich tych zagadnień będzie stanowiło podstawę do stwierdzenia, że podstawą działania organów w sferze planowania i zagospodarowania przestrzennego był, obok ładu przestrzennego, zrównoważony rozwój. Warto również podkreślić, że zasada zrównoważonego rozwoju odgrywa obecnie niewątpliwie niebagatelną rolę w działalności planistycznej organów administracji publicznej, co należy ocenić pozytywnie. Potwierdzają to realizowane coraz częściej projekty związane m.in. z inwestycjami dotyczącymi pozyskiwania energii ze źródeł odnawialnych. ${ }^{23}$

\section{BIBLIOGRAFIA}

Hauser R., Mzyk E., Niewiadomski Z., Rzążewska M., Ustawa o zagospodarowaniu przestrzennym z komentarzem i przepisami wykonawczymi, Warszawa 1995.

Niewiadomski Z. (red.), Ustawa o planowaniu i zagospodarowaniu przestrzennym. Komentarz, Warszawa 2004.

Niewiadomski Z., Planowanie przestrzenne. Zarys systemu, Warszawa 2003.

Nowicki H., [w:] W. Szwajdler (red.), Aspekty prawne planowania i zagospodarowania przestrzennego, Warszawa 2013.

Radecki W., Sommer J., Szostek W., Ustawa o zagospodarowaniu przestrzennym oraz wybrane przepisy wykonawcze. Komentarz, Wrocław 1995.

Sokólska E., Kłopotowski A., Dojlidy Górne niezgody. Mieszkańcy kontra magistrat, http://bialystok. gazeta.pl/bialystok/1,35250,11955262,Dojlidy_Gorne_niezgody_Mieszkancy_kontra_magistrat.html

Stępień E., Rynek energetyczny przyszłością PPP?, „Forum PPP. Magazyn inwestycji publicznych” 2013, nr 1 (22).

Szewczyk M., [w:] Z. Leoński, M. Szewczyk, Zasady prawa budowlanego i zagospodarowania przestrzennego, Bydgoszcz-Poznań 2002.

Szewczyk M., [w:] Z. Leoński, M. Szewczyk, M. Kruś, Prawo zagospodarowania przestrzeni, Warszawa 2012.

Zimmermann J., Prawo administracyjne, Warszawa 2012. 


\section{CONCEPT OF SUSTAINABLE DEVELOPMENT ON THE BASIS OF THE LAW OF 27 MARCH 2003 ON SPATIAL PLANNING AND DEVELOPMENT}

The article discusses issues related to the concept of sustainable development on the basis of the law of 27 March 2003 on spatial planning and development. When analyzing the current legislation from the perspective of doctrine and administrative and court decisions, concerns arising from the application of the principle of sustainable development and the realization of selected acts of planning value were noted.

Keywords: sustainable development, spatial planning and development, planning acts 